THE POWER OF DIALOGUE BETWEEN ISRAELIS AND PALESTINIANS 



\section{THE POWER OF DIALOGUE}

BETWEEN

ISRAELIS AND

PALESTINIANS

Stories of Change from the School for Peace

NAVA SONNENSCHEIN

EDITED AND TRANSLATED BY DEB REICH

Til

RUTGERS UNIVERSITY PRESS

New Brunswick, Camden, and Newark, New Jersey, and London 
A British Cataloging-in-Publication record for this book is available from the British Library.

Library of Congress Cataloging-in-Publication Data

Names: Sonnenschein, Nava, 1953- author. | Reich, Deb, translator.

Title: The power of dialogue between Israelis and Palestinians : stories of change from the School for Peace / by Nava Sonnenschein ; translated by Deb Reich.

Description: New Brunswick : Rutgers University Press, 2019. | Includes

bibliographical references.

Identifiers: LCCN 2017059909| ISBN 9780813599229 (cloth : alk. paper) |

ISBN 9780813599212 (pbk. : alk. paper)

Subjects: LCSH: Multicultural education-Israel. | Neve shalom (School) |

Arab-Israeli conflict-1993-Peace.| Jews-Israel-Interviews. | Palestinian

Arabs-Israel-Interviews. | Conflict management-Israel. | Israel—Ethnic relations.

Classification: LCC LC1099.5.I75 S6513 2019 | DDC 370.117095694-dc23

LC record available at https://lccn.loc.gov/2017059909

Copyright (C) 2019 by Nava Sonnenschein

All rights reserved

No part of this book may be reproduced or utilized in any form or by any means, electronic or mechanical, or by any information storage and retrieval system, without written permission from the publisher. Please contact Rutgers University Press, 106 Somerset Street, New Brunswick, NJ 08901. The only exception to this prohibition is "fair use" as defined by U.S. copyright law.

( $)$ The paper used in this publication meets the requirements of the American National Standard for Information Sciences-Permanence of Paper for Printed Library Materials, ANSI Z39.48-1992.

www.rutgersuniversitypress.org

Manufactured in the United States of America 